\title{
UNCOVERING DEGREES OF WORKPLACE BULLYING: A COMPARISON OF BACCALAUREATE NURSING STUDENTS' EXPERIENCES DURING CLINICAL PLACEMENT IN AUSTRALIA AND THE UK
}

Short title: Uncovering degrees of workplace bullying

\section{AUTHORS}

Professor Melanie Birks, RN, PhD, MEd, BN, FACN

Head - Nursing, Midwifery and Nutrition

College of Healthcare Sciences

Centre of Nursing and Midwifery Research

James Cook University

Townsville, Qld, Australia

Dr Robyn P Cant

Nursing, Midwifery and Nutrition

James Cook University

Townsville, Qld, Australia

Dr Lea M. Budden

Senior Lecturer

College of Healthcare Sciences

Centre of Nursing and Midwifery Research

James Cook University

Townsville, Qld, Australia

Professor Michele Russell-Westhead EdD, MSc, PGCE, PFHEA

Academic Lead Educational Development

King's Teaching Fellow,

Professor of Clinical, Professional and Higher Education (Northumbria University),

Florence Nightingale Faculty of Nursing and Midwifery

Ms Yeter Sinem ÜZAR ÖZÇETIN

Research Assistant, RN, MSc, PhD Student

Hacettepe University Faculty of Nursing

Psychiatric Nursing Department

06100 Ankara/TURKEY

Professor Stephen Tee DClinP, MA, PGCEA, BA, DPSN, RMN, PFHEA

Executive Dean and Professor of Nurse Education

Faculty of Health and Social Sciences

Bournemouth University 


\section{RESEARCH HIGHLIGHTS}

Few studies have explored nursing students' experience of bullying on placement One-third to one half of UK and Australian respondents experienced bullying Types and reasons for negative behaviours experienced by students are explored Similarities and differences amongst Australian and UK students are identified Recommendations are made for managing this unacceptable behaviour

\section{ABSTRACT}

Background: Bullying in health workplaces has a negative impact on individual nurses, their families, multidisciplinary teams, patient care and the profession.

Aim: This paper compares the experiences of bully and harassment of Australian and UK baccalaureate nursing students during clinical placement.

Method: A secondary analysis was conducted on two primary cross-sectional studies of bullying experiences of Australian and UK nursing students. Data were collected using the SEBDCP questionnaire and analysed using descriptive and inferential statistics. The total sample consisted of 833 Australian and 561 UK students

Results: Australian nursing students experienced a higher rate of bullying (50.1\%) than UK students (35.5\%). Across both cohorts (Aust 53\%, UK 68\%). students identified other nurses as the main perpetrators and few bullied students chose to report the episode/s (Aust 28.5\%, UK 19.4\%). The main reason given for not reporting was fear of being victimised (Aust $53.6 \%$, UK 54.5\%). Sadly, a number felt 'it is part of the job' (UK: $21.6 \%$, Aust: $23.9 \%$ ).

Conclusions: It is clear that a culture of bullying in nursing persists internationally. Nursing students are vulnerable and often experience and/or witness bullying episodes during clinical placement, leading them to question their future in the 'caring' profession of nursing. Bullying behaviour requires a zero tolerance by the nursing profession and education providers need to develop clear policies and implement procedures that protect students as the future nursing workforce. 


\section{INTRODUCTION}

Research indicates that bullying and harassment in the form of verbal, physical or psychological aggression in clinical work settings is a global phenomenon. Although bullying is documented in numerous employment fields (Zapf, 2011), bullying in nursing is of particular concern because it has become historically entrenched, and the sources of bullying are often other nurses or health professionals (Cooper \& Curzio, 2012) or even patients (Hinchberger, 2009). Healthcare changes and subsequent organisational factors such as the misuse of processes and procedures contribute to the culture and perpetuate the experiences of bullying by nurses (Blackstock, Harlos, Macleod, \& Hardy, 2015). Bullying and harassment in the workplace involves verbal, physical, social or psychological abuse by another person or group of people at work (Australian Human Rights Commission, 2013) that can be horizontal or vertical (Birks, Budden, Stewart, \& Chapman, 2014) .

Hewett (2010) described degrees of aggression towards another individual that could be expressed as physical or non-physical abuse. In the healthcare literature, bullying is often used interchangeably with workplace violence, aggression, incivility and harassment. Bullying in nursing is prevalent and visible and is the antithesis of caring which is the foundation of the profession (Adams \& Maykut, 2015). In the case of nursing students however, research more commonly reports bullying by an individual who has a higher level of authority, thus the violence is vertical in the form of overt or covert acts of aggression (Bowllan, 2015).

Nursing is already a hierarchical profession that is said to be 'born in the church and raised in the military', a quote attributed to Florence Nightingale herself and based on her own religious upbringing. The association with these highly disciplined institutions reflects the traditional perception that nursing must be defined by order and obedience. With the evolution of society and advances in healthcare over the last century, nursing has developed as a profession, characterised by autonomy, accountability and an independent body of knowledge. In spite of this progress, nurses are prone to feelings of being an 'oppressed group'; with negative behaviours fuelled by low personal self-esteem and a group-mediated identity (Roberts, Demarco, \& Griffin, 2009). Hutchinson (2013) further posits bullying in nursing as a form of workplace manipulation, potentially socializing newcomers into a culture that may include being tolerant of bullying in various forms.

To achieve a registered-nurse qualification in both Australia and the UK, nursing students complete a minimum three-year baccalaureate (or bachelors) degree in nursing, with a handful of institutions across both nations offering programs up to four years duration. In 
these programs, time is divided between classroom-based activities and clinical practice placements in a health service. Accreditation requirements dictate a minimum of 800 placement hours in Australia and 2300 hours in UK, with both involving a prolonged period of exposure to the clinical environment in the final year of study (Australian Nursing and Midwifery Accreditation Council, 2012; Nursing and Midwifery Council UK, 2011). As novice healthcare professionals, nursing students are susceptible to the differential effect of power if it is exercised inappropriately. Bullying and increased aggression by staff and/or patients may form a barrier to students' socialisation into nursing (Bowllan, 2015) and lead to sabotage of their learning experience and development of caring behaviours for patients (Adams \& Maykut, 2015).

The literature indicates that nursing students worldwide experience bullying. In studies since 2009, one-third of 346 Italian nursing students reported at least one occasion of upsetting verbal or physical violence in the clinical setting (Magnavita \& Heponiemi, 2011). In Taiwan, $41.7 \%$ of 156 surveyed nursing students reported being bullied through unfriendly behaviour and excess criticism (Chang, 2012); in Canada over $88 \%$ of 674 students across all four years of a nursing degree reported at least on occasion of bullying behaviour during clinical education (Clarke, Kane, Rajacich, \& Lafreniere, 2012), and in the USA, 100\% of 129 surveyed nursing students had experienced bullying in one form or another (Hinchberger, 2009). Thomas and Burk (2009) in a descriptive study of junior student nurses' experiences in clinical placement in USA, reported that the main source of students' distress was feelings of injustice owing to unfair treatment. RNs were the main perpetrators of unjust behaviours through being rude, condescending, sarcastic, disrespectful, and degrading, whilst students felt unwanted and ignored by those who bore responsibility for welcoming them to the profession.

In Australia over a decade ago, Jackson et al. (2002) called for better recognition of nursing workplace violence including bullying, linking this to issues of low recruitment and lack of nursing staff retention. Few outcomes are known, however. Recently, in both Australia and the UK, nursing students' experience of workplace violence and bullying has been explored through national surveys of students enrolled in undergraduate nursing degrees (Blinded for review Au; Blinded for review UK). These studies found that bullying had been experienced by a proportion of students in all levels of their nursing program during clinical placements. Again, the main perpetrators were health service employees and nursing staff. A secondary analysis of these two earlier studies was conducted to uncover similarities and differences in nursing students' experiences and the findings are presented in this paper. The 
findings and subsequent discussion will help nursing leaders and educators to understand the antecedents of bullying, recognize the impact of this phenomenon on nursing students and develop strategies to reduce, mitigate and manage workplace violence in respect of this vulnerable group.

\section{METHODS}

The two studies reported here employed a cross-sectional survey design, utilising the Student Experience of Bullying during Clinical Placement (SEBDCP) questionnaire (Blinded for review $\mathrm{Au}$ ). The questionnaire was developed from the work of Hewett (2010) and adapted for the Australian and subsequently the UK contexts. The SEBDCP comprised 13 main questions with over 80 items, most requiring a rating of frequency of occurrence: 'Never' (0 times); 'Occasionally' (1-2 times) ; 'Sometimes' (3-5 times) and 'Often' ( $>5$ times). Each question offered an 'Other' response category with the option to provide further details. In the primary Australian study, the survey subscales were found to be reliable with Cronbach alpha coefficients: Non-violent behaviour 0.93; Physical behaviour 0.66; Sexual harassment 0.72; In addition, for both cohorts a short socio-demographic question set sought personal information such as age, gender, ethnicity, program of enrolment and year of study.

A definition of bullying was purposely not provided on the questionnaire in order to allow participants broad disclosure. As a baseline question, respondents were asked whether or not they had been bullied and/or harassed (rated as 'yes'/'no'/'unsure'). Regardless of how participants responded to the baseline question, all were presented with questions about specific acts of behaviour in order not to pre-empt students' perceptions of what constituted bullying. Respondents were asked to indicate whether they have been exposed to these behaviours during while on clinical placement in the previous year, including providing information about clinical settings, perpetrator/s, and whether incidents were reported.

\section{Survey administration}

For the Australian survey, the questionnaire was administered electronically using a commercial Internet provider between October and December 2014. Recruitment occurred via heads of Schools of Nursing across Australia, who were all asked to pass the survey link to students enrolled in undergraduate nursing programs. Results have been reported in a previous published primary paper (Blinded for review $\mathrm{Au}$ ).

A subsequent study was conducted in the UK (Blinded for review UK) that followed the same research design and utilized the SEBDCP questionnaire, with minor amendments 
made to the demographic items to ensure relevance to context. A convenience sample was drawn from approximately one-third of the schools of nursing across the UK, who were asked to pass on the invitation and electronic survey link to their nursing students. Participating students were asked to describe the incidence and experiences of bullying and/or harassment during clinical placement in 2015.

\section{Sample and Analysis}

A secondary analysis of both datasets was conducted using IBM-SPSS 23 (IBM Corp., Armonk, New York, 2013). For the current exercise and to explore the experiences of baccalaureate nursing students alone, a sample totalling 1,394 was extracted for analysis. This comprised $n=833$ Australian and $n=561$ UK students. Students were included when they specified enrolment in years 1, 2, or 3 of their program. Students indicating enrolment in fourth year, enrolment in a dual qualification or who failed to specify their year of enrolment were excluded to reduce potential for identification, remove any confounding data and support equivalency in comparison.

Numerical and categorical data were summed and then subjected to inferential statistical tests. Each response set was tested for association between bullied (or not) and other variables such as participants' age, gender, ethnic background, country of birth, main language being English, year of program, and experience of specified behaviours. Relationships between the influencing demographic variables and behavioural items were tested, and association between selected results in the two cohorts were statistically examined. The analysis used $t$-test (e.g. for age) or non-parametric tests such as Pearson's Chi-square test of independence for categorical variables, Mann-Whitney U, or Spearman's correlation - as appropriate. $\mathrm{P}<0.05$ was set as the level of significance.

\section{RESULTS}

The characteristics of participating baccalaureate nursing students from Australia $(n=833)$ and from the UK $(n=561)$ are presented in Table 1. Students were principally female (89.5\%), predominantly aged less than 30 years (median age Aust: 26; UK: 23), of white Caucasian background with English as the first language. Over three-quarters (81.2\%) were born in the country of survey origin, although the Australian cohort included significantly more overseas-born students (Aust 23.5\% vs UK 11.0\%) whereby English was not their first language (14.6\% vs UK 6.8\%). The proportion of males in the UK cohort was small (7.8\%; $n$ $=44)$ versus $11.6 \%(n=96)$ male Australian nursing students. 
Participants in both countries represented the three years of the nursing programs. In Australia, participants were from all eight states and territories. All four nations of the UK and Ireland were represented, with highest number of responses from the southeast UK $(43.7 \%)$.

Table 1: Demographic characteristics of baccalaureate nursing students and experience of bullying by cohort $(\mathrm{N}=1,394)$

\begin{tabular}{|c|c|c|c|c|}
\hline Item & & $\begin{array}{l}\text { Australia } \\
(\mathrm{n}=833)\end{array}$ & $\begin{array}{l}\text { UK } \\
(\mathrm{n}=561)\end{array}$ & $\begin{array}{l}\text { Total } \\
\text { N }(\%)\end{array}$ \\
\hline Sex & Male & $96(11.6)$ & $44(7.8)$ & $140(10.0)$ \\
\hline & Female & $731(88.4)$ & $517(92.2)$ & $1,248(90.0)$ \\
\hline Age & Years & $\begin{array}{l}\text { median } 26 \\
\text { (range 18-60) }\end{array}$ & $\begin{array}{l}\text { median } 23 \\
\text { (range 18-58) }\end{array}$ & \\
\hline Country of birth & $\begin{array}{l}\text { Born in Australia } \\
\text { Born in UK }\end{array}$ & $\begin{array}{l}633(76.5) \\
-\end{array}$ & $\begin{array}{l}- \\
499(88.9)\end{array}$ & \\
\hline Ethnic background & $\begin{array}{l}\text { (White) } \\
\text { British/EU/other } \\
\text { nationals } \\
\text { South/East Asian } \\
\text { (Black) } \\
\text { African/EU/other } \\
\text { nation } \\
\text { Indigenous Australian }\end{array}$ & $19(2.3)$ & $\begin{array}{l}504(89.8) \\
22(4.0) \\
32(5.7)\end{array}$ & \\
\hline $\begin{array}{l}\text { English is first } \\
\text { language }\end{array}$ & Yes & $710(85.4)$ & $523(93.2)$ & $1,233(88.4)$ \\
\hline $\begin{array}{l}\text { Year of current BN } \\
\text { enrolment }\end{array}$ & $\begin{array}{l}\text { Year } 1 \\
\text { Year } 2 \\
\text { Year } 3\end{array}$ & $\begin{array}{l}189(22.7) \\
268(32.2) \\
376(45.1)\end{array}$ & $\begin{array}{l}193(35.1) \\
208(37.8) \\
149(27.1)\end{array}$ & $\begin{array}{l}382(27.6) \\
476(34.1) \\
525(37.8)\end{array}$ \\
\hline $\begin{array}{l}\text { Experienced } \\
\text { bullying/ harassment } \\
\text { on placement in past } \\
\text { year }\end{array}$ & $\begin{array}{r}\text { Yes } \\
\text { No } \\
\text { Unsure }\end{array}$ & $\begin{array}{l}417(50.1) \\
312(37.5) \\
104(12.5) .\end{array}$ & $\begin{array}{l}199(35.5) \\
219(39.0) \\
84(15.0)\end{array}$ & $\begin{array}{l}616(46.1) \\
531(39.8) \\
188(14.0)\end{array}$ \\
\hline $\begin{array}{l}\text { Proportion of bullied } \\
\text { students per each } \\
\text { year of program }\end{array}$ & $\begin{array}{l}\text { Year } 1 \\
\text { Year } 2 \\
\text { Year } 3\end{array}$ & $\begin{array}{l}50(26.0) \\
141(52.6) \\
228(60.6)\end{array}$ & $\begin{array}{l}67(34.7) \\
69(33.1) \\
58(38.9)\end{array}$ & - \\
\hline
\end{tabular}




\begin{tabular}{|c|c|c|c|c|}
\hline \multirow{3}{*}{$\begin{array}{l}\text { Healthcare setting } \\
\text { where bullying was } \\
\text { ever experienced } \uparrow\end{array}$} & Hospital & $378(72.0)$ & $177(74.3)$ & \multirow[t]{3}{*}{-} \\
\hline & Community/clinic & $95(18.1)$ & $53(22.2)$ & \\
\hline & Other & $51(9.7))$ & $8(3.3)$ & \\
\hline
\end{tabular}

$\dagger$ Based on rating responses per case extracted from: occasionally/sometimes/often

\section{Prevalence of bullying}

The characteristics of students who reported they were bullied were examined. There was a significantly higher rate of bullying experienced in the Australian BN cohort $(50.1 \%)$ compared with the UK BN student group $(35.5 \%)\left(\chi^{2}(2, n=1,394)=182.783, p=0.000\right)$. Nevertheless, irrespective of the different level of prevalence the impact is profound:

"I feel as a student nurse it happens all the time and sometimes it makes you feel so worthless and has a massive impact on my self-confidence." (Female second year student - UK).

When bullying was examined by gender, there was a significant difference in the Australian cohort with more females $(51.4 \%)$ than males $(39.6 \%)$ experiencing bullying during clinical placement $\left(\chi^{2}(1, n=414)=275.952, p=0.000\right)$. This pattern reversed in the UK group with a trend towards a higher rate of bullying of males $(45.5 \% ; n=20$ of 44 males) versus $33.3 \%$ $(n=172)$ of females; however this did not reach a level of significant difference.

There was also, however, a relatively high degree of uncertainty among both cohorts about how students perceived or self-defined what was bullying, with almost 200 students (13\%) uncertain when answering the question asking whether they were bullied or not. In Australia, males were particularly uncertain (males 17\%; females $12.0 \%$ ) while in the UK, $13.6 \%(n=70)$ of females and only three males were uncertain.

"It was more subtle, more like incivility" (Male third year student - Australia)

\section{Antecedent factors}

Other response variables were tested to examine antecedents that might help explain the degree to which students were exposed to bullying or uncivil behaviours. Advancement through the program was significantly correlated with an increasing rate of experience of bullying in the Australian cohort alone. 


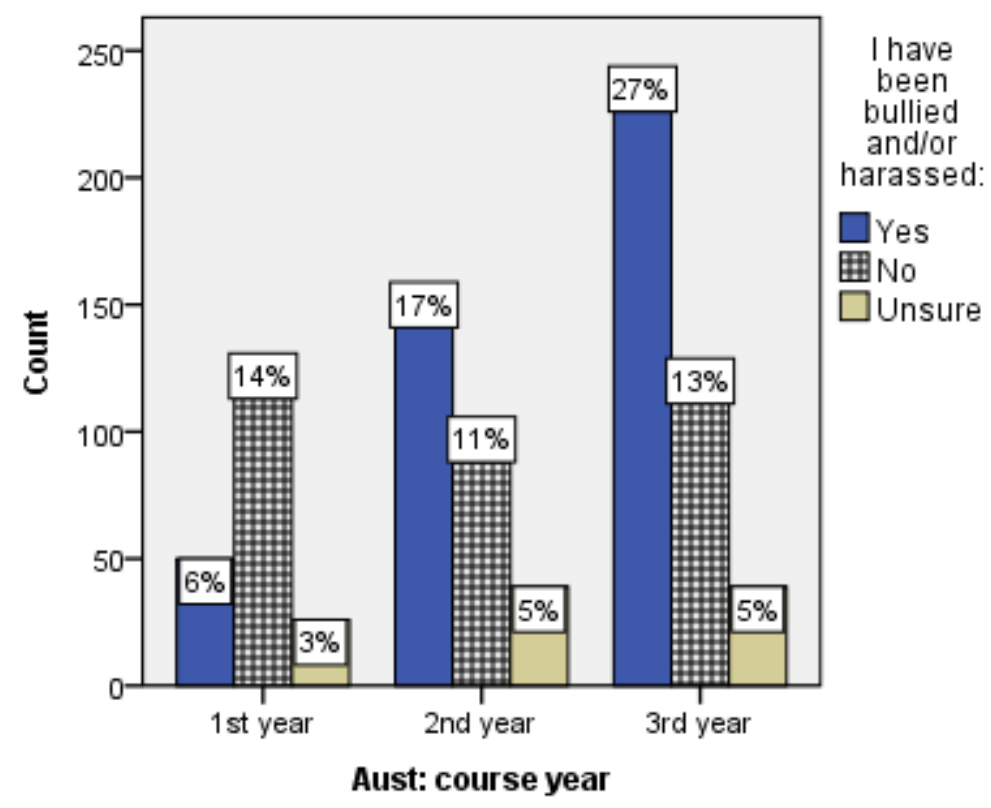

Figure 1: Australian cohort- prevalence of bullying as a percentage of the whole cohort by enrolled year $(n=833)$

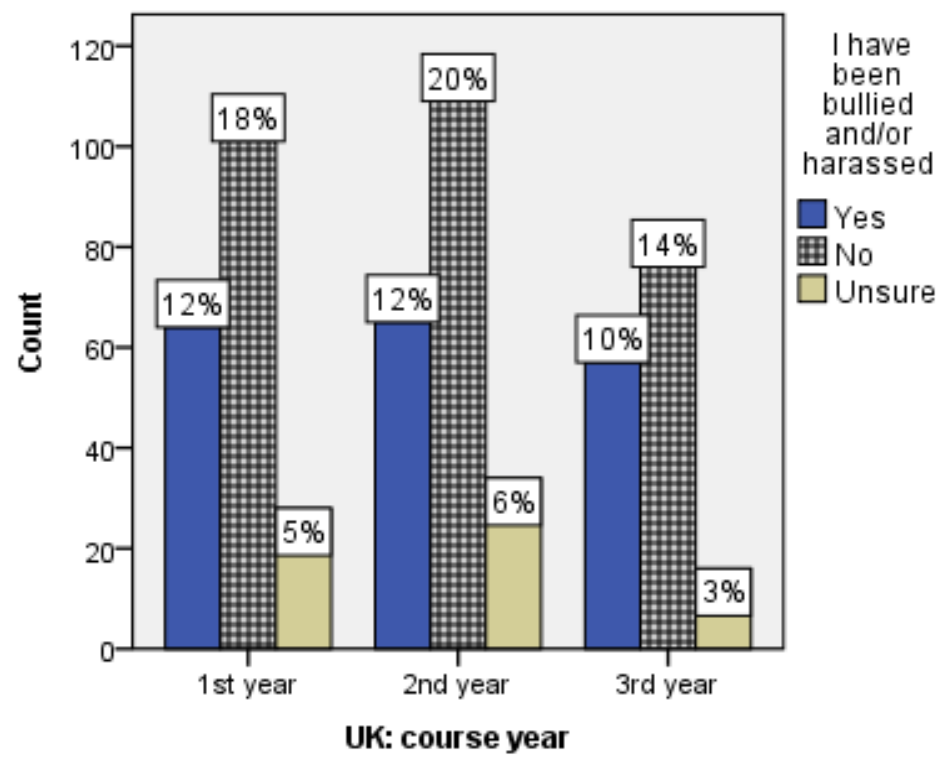

Figure 2: UK cohort- prevalence of bullying as a percentage of the whole cohort by enrolled year $(n=561)$

As seen in Figure 1, in the Australian cohort there was significant difference by year $\left(\chi^{2}(4, n=833)=64.487, p=0.000\right)$, with those currently enrolled in third year experiencing 
the highest rate of bullying of all the years. In the UK cohort, as seen in Figure 2, the proportion of students experiencing bullying was not significantly different between years 1 , 2 and 3 (see also Table 1). The geographic region of the students' university was not implicated.

Students' age did not influence bullying experiences, as there was no significant association between the students' age and experience of being bullied in either cohort. UK students' age when grouped by decade showed somewhat consistent bullying. Further, regarding birthplace, there was no significant association between being born in Australia or being born in the UK, and experiencing bullying in the home country.

Students' cultural background was, however, implicated, as some elements of ethnicity were associated with bullying. It was noted that the UK students were predominantly a Caucasian racial profile, from British, Irish, EU nations or other white ethnic groups. For UK students from African/Caribbean or other races that were black there was a trend of more bullying as 27 of 32 students stated they experienced bullying. Only data relating to Indigenous status was collected for the Australian cohort, for which the incidence of bullying was consistent with the rest of this sample.

Of 35 UK students for whom English was not their first language, half ( $\mathrm{n}=18 ; 51 \%)$ experienced bullying compared with around one-third (33\%) of native English speakers; a significant difference $\left(\chi^{2}(2, n=561)=6.695, p=0.035\right)$. Conversely, Australian students whose first language was not English were no more likely to experience bullying than native English speakers. Of non-native English speaker students in Australia, $n=66(54.5 \%)$ experienced bullying versus $n=350$ (49.3\%) for native English speakers), even though the proportion of this student group in Australia (14.6\%) was larger than in the UK (6.2\%).

\section{Perpetrators of bullying}

As shown in Table 1, bullying was reported to occur mainly in hospital settings with little response about community or other settings. Hospitals afford a hierarchy of nursing staff who work with students on a daily shift basis to preceptor, mentor, or supervise students while they perform nursing tasks. Registered nurses, preceptors/mentors, nurse managers, and health care assistants in nursing were consistently mentioned as the key perpetrators of bullying of nursing students. This was true for both the Australian (53\%) and UK (68\%) cohorts. 
"It is often senior nurses and clinical education staff that bully junior nurses and nursing students. Some feel intimidated when you demonstrate knowledge and prefer you to remain quiet." (Female third year student - Australia).

"Bullying occurred after I had made a complaint to an appropriate staff member at the university, who then passed on my remarks (with the best of intentions, I am sure) to my mentor" (Female third year - UK).

\section{Types of bullying behaviour}

As students try to cope with stresses of a new workplace, a key source of nursing students' anxiety and is the idea of being unjustly treated or humiliated. Table 2 displays the reported frequency of these uncivil or bullying behaviours from both student cohorts. The data presented using the summed responses 'sometimes' and 'often' is useful to portray the breadth of experiences perceived to have occurred not just once or twice, but three or more times. The behaviours involved injustice incidents, unfair treatment and public humiliation. Around $10 \%$ experienced some form of sexual harassment. From observing the number of students who have 'never' experienced these behaviours, it is apparent that by far the majority of students, around two-thirds, had experienced many of these issues.

"To a certain extent, I think it is assumed that you will encounter it at some stage, and if you don't, you've just been lucky." (Female second year student - Australia).

A statistical comparison was made between cohorts using frequency response ratings (never/occasionally/sometimes/often) (Table 2). There was a significant difference between cohorts in six of eighteen items. Ranked results showed that Australian students indicated that they were significantly more harshly judged, ridiculed, unfairly criticized or more often exposed to a racist remark. UK students, on the other hand, indicated through their ratings that they were more often given unfair work allocations or rostering schedules. For the remaining twelve items, there was no difference in frequency of perceived bullying and uncivil behaviour between cohorts. 
Table 2: Number of students who experienced bullying behaviours by cohort, and betweengroup comparisons

\begin{tabular}{|c|c|c|c|c|c|c|c|}
\hline & \multicolumn{3}{|c|}{$\begin{array}{l}\text { Australian cohort } \\
\text { Frequency }\end{array}$} & \multicolumn{3}{|c|}{$\begin{array}{l}\text { UK cohort } \\
\text { Frequency }\end{array}$} & \multirow[b]{2}{*}{$\begin{array}{l}Z \begin{array}{l}Z \text { score (p } \\
\text { value) }\end{array}\end{array}$} \\
\hline & $\begin{array}{l}\text { Sometime } \\
\text { s/often } \\
\text { n }(\%)\end{array}$ & $\begin{array}{l}\text { Occasion } \\
\text { ally } \\
\text { n }(\%)\end{array}$ & $\begin{array}{l}\text { Never } \\
\text { n }(\%)\end{array}$ & $\begin{array}{l}\text { Sometime } \\
\text { s/often } \\
\text { n }(\%)\end{array}$ & $\begin{array}{l}\text { Occasion } \\
\text { ally } \\
\text { n }(\%)\end{array}$ & $\begin{array}{l}\text { Never } \\
\text { n }(\%)\end{array}$ & \\
\hline \multicolumn{8}{|l|}{ Public humiliation } \\
\hline $\begin{array}{l}\text { Negative non-verbal } \\
\text { behaviour eg, raised } \\
\text { eyebrows, rolling of } \\
\text { eyes }\end{array}$ & $373(48.5)$ & \begin{tabular}{|l}
237 \\
$(31.2)$
\end{tabular} & $\begin{array}{l}149 \\
(19.6)\end{array}$ & $220(45.6)$ & $176(36.9)$ & $86(17.8)$ & $\begin{array}{l}-0.875 \\
(0.381)\end{array}$ \\
\hline $\begin{array}{l}\text { Treated as though I } \\
\text { am not part of the } \\
\text { multidisciplinary } \\
\text { team }\end{array}$ & $254(34.2)$ & $\begin{array}{l}238 \\
(32.0)\end{array}$ & $\begin{array}{l}251 \\
(33.8)\end{array}$ & $146(30.2)$ & $169(35.0)$ & $\begin{array}{l}168 \\
(34.8)\end{array}$ & $\begin{array}{l}-1.185 \\
(0.236)\end{array}$ \\
\hline Ridiculed & $145(19.5)$ & $\begin{array}{l}145 \\
(19.6)\end{array}$ & $\begin{array}{l}451 \\
(60.9)\end{array}$ & 63(13.3) & $82(17.3)$ & $\begin{array}{l}330 \\
(69.5)\end{array}$ & $\begin{array}{l}-3.266 \\
(0.001)^{*}\end{array}$ \\
\hline $\begin{array}{l}\text { Verbally abused } \\
\text { (sworn, shouted or } \\
\text { yelled at) }\end{array}$ & $100(14.9)$ & $\begin{array}{l}159 \\
(21.4)\end{array}$ & $\begin{array}{l}473 \\
(63.7)\end{array}$ & $59(12.3)$ & $101(21.0)$ & $\begin{array}{l}321 \\
(66.7)\end{array}$ & $\begin{array}{l}-1.235 \\
(0.217)\end{array}$ \\
\hline $\begin{array}{l}\text { Exnosed to a racist } \\
\text { remark }\end{array}$ & $66(8.9)$ & $72(9.8)$ & $\begin{array}{l}599 \\
(81.3)\end{array}$ & $17(4.4)$ & $35(7.4)$ & $\begin{array}{l}420 \\
(88.2)\end{array}$ & $\begin{array}{l}-4.166 \\
(<0.001)^{*}\end{array}$ \\
\hline \multicolumn{8}{|l|}{ Injustice incidents } \\
\hline Ignored & $350(46.3)$ & $\begin{array}{l}248 \\
(32.8)\end{array}$ & $\begin{array}{l}158 \\
(20.9)\end{array}$ & $230(47.8)$ & $151(31.4)$ & $\begin{array}{l}100 \\
(20.8)\end{array}$ & $\begin{array}{l}-0.189 \\
(0.850)\end{array}$ \\
\hline Neglected & $265(35.4)$ & $\begin{array}{l}221 \\
(29.5)\end{array}$ & $\begin{array}{l}262 \\
(35.0)\end{array}$ & $162(34.6)$ & $113(23.8)$ & $\begin{array}{l}197 \\
(41.6)\end{array}$ & $\begin{array}{l}-1.888 \\
(0.059)\end{array}$ \\
\hline Unfairly criticized & $250(33.0)$ & $\begin{array}{l}238 \\
(31.4)\end{array}$ & $\begin{array}{l}269 \\
(35.5)\end{array}$ & $129(27.1)$ & $146(30.6)$ & $\begin{array}{l}203 \\
(42.3)\end{array}$ & $\begin{array}{l}-2.621 \\
(0.009)^{*}\end{array}$ \\
\hline Harshly judged & $256(33.9)$ & $\begin{array}{l}220 \\
(29.2)\end{array}$ & $\begin{array}{l}278 \\
(36.9)\end{array}$ & $122(25.7)$ & $140(29.5)$ & $\begin{array}{l}213 \\
(44.8)\end{array}$ & $\begin{array}{l}-3.396 \\
(<0.001)^{*}\end{array}$ \\
\hline \multicolumn{8}{|l|}{$\begin{array}{l}\text { Unfairly treated at } \\
\text { work }\end{array}$} \\
\hline $\begin{array}{l}\text { Denied learning } \\
\text { opportunities }\end{array}$ & $226(30.3)$ & $\begin{array}{l}213 \\
(28.5)\end{array}$ & $\begin{array}{l}308 \\
(41.2)\end{array}$ & $143(30.0)$ & $139(29.1)$ & $\begin{array}{l}195 \\
(40.9)\end{array}$ & $\begin{array}{l}-0.119 \\
(0.905)\end{array}$ \\
\hline $\begin{array}{l}\text { Denied } \\
\text { acknowledgement } \\
\text { for good work }\end{array}$ & $203(27.3)$ & $\begin{array}{l}207 \\
(27.7)\end{array}$ & $\begin{array}{l}336 \\
(45.0)\end{array}$ & $129(27.0)$ & $135(28.2)$ & $\begin{array}{l}215 \\
(44.9)\end{array}$ & $\begin{array}{l}-0.130 \\
(0.896)\end{array}$ \\
\hline $\begin{array}{l}\text { Given unfair work } \\
\text { allocation }\end{array}$ & $141(19.0)$ & $\begin{array}{l}135 \\
(18.3)\end{array}$ & $\begin{array}{l}462 \\
(62.6)\end{array}$ & $118(19.3)$ & $112(23.4)$ & $\begin{array}{l}250 \\
(52.3)\end{array}$ & $\begin{array}{l}-3.349 \\
(0.001)^{*}\end{array}$ \\
\hline $\begin{array}{l}\text { Unfairlv treated } \\
\text { regarding rostering } \\
\text { schedules }\end{array}$ & $73(8.5)$ & $87(11.8)$ & $\begin{array}{l}589 \\
(79.7)\end{array}$ & $85(17.8)$ & $79(16.5)$ & $\begin{array}{l}314 \\
(65.7)\end{array}$ & $\begin{array}{l}-5.560 \\
(0.001)^{*}\end{array}$ \\
\hline \multicolumn{8}{|l|}{ Sexual harassment } \\
\hline $\begin{array}{l}\text { Exposed to a sexist } \\
\text { remark }\end{array}$ & $29(3.9)$ & $83(11.0)$ & $\begin{array}{l}641 \\
(85.1)\end{array}$ & $17(4.9)$ & $35(7.4)$ & $\begin{array}{l}420 \\
(88.2)\end{array}$ & $\begin{array}{l}-0.251 \\
(0.802)\end{array}$ \\
\hline
\end{tabular}




\begin{tabular}{|l|l|l|l|l|l|l|l|}
\hline $\begin{array}{l}\text { Been inappropriately } \\
\text { touched }\end{array}$ & $17(2.3)$ & $64(8.5)$ & $\begin{array}{l}674 \\
(89.3)\end{array}$ & $7(1.4)$ & $32(6.6)$ & $\begin{array}{l}445 \\
(91.9)\end{array}$ & $\begin{array}{l}-1.564 \\
(0.118)\end{array}$ \\
\hline $\begin{array}{l}\text { Unwanted request } \\
\text { for intimate physical } \\
\text { contact }\end{array}$ & $10(1.4)$ & $38(5.1)$ & $\begin{array}{l}703 \\
(97.6)\end{array}$ & $9(1.9)$ & $34(7.1)$ & $\begin{array}{l}436 \\
(91.0)\end{array}$ & $\begin{array}{l}-1.689 \\
(0.091)\end{array}$ \\
\hline $\begin{array}{l}\text { A suggestive sexual } \\
\text { gesture directed at } \\
\text { me }\end{array}$ & $30(4.0)$ & $67(8.9)$ & $\begin{array}{l}654 \\
(87.1)\end{array}$ & $19(3.9)$ & $59(12.2)$ & $\begin{array}{l}405 \\
(83.9)\end{array}$ & $\begin{array}{l}-1.517 \\
(0.129)\end{array}$ \\
\hline $\begin{array}{l}\text { Been threatened with } \\
\text { sexual assault }\end{array}$ & $1(0.1)$ & $8(1.1)$ & $\begin{array}{l}744 \\
(98.8)\end{array}$ & $0(0.0)$ & $4(0.8)$ & $\begin{array}{l}480 \\
(99.2)\end{array}$ & $\begin{array}{l}-0.622 \\
(0.534)\end{array}$ \\
\hline
\end{tabular}

*Mann-Whitney U tests indicated significant difference between cohorts on ranked responses: Sometimes $=3-5$ times; Often $=>5$ times; Occasionally' $=(1-2$ times $)$; or Never $=0$ times.

Table 3: Number of students who experienced physical violence by cohort, and betweengroup comparisons

\begin{tabular}{|c|c|c|c|c|c|c|c|}
\hline & \multicolumn{3}{|c|}{$\begin{array}{l}\text { Australian cohort } \\
\text { Frequency }\end{array}$} & \multicolumn{3}{|c|}{$\begin{array}{l}\text { UK cohort } \\
\text { Frequency }\end{array}$} & \multirow[b]{2}{*}{$\begin{array}{l}Z \text { score }(p \\
\text { value })\end{array}$} \\
\hline & $\begin{array}{l}\text { Sometime } \\
\text { s/often } \\
\text { n }(\%)\end{array}$ & $\begin{array}{l}\text { Occasion } \\
\text { ally } \\
\text { n }(\%)\end{array}$ & $\begin{array}{l}\text { Never } \\
\text { n }(\%)\end{array}$ & $\begin{array}{l}\text { Sometime } \\
\text { s/often } \\
\text { n }(\%)\end{array}$ & $\begin{array}{l}\text { Occasion } \\
\text { ally } \\
\text { n }(\%)\end{array}$ & $\begin{array}{l}\text { Never } \\
\text { n }(\%)\end{array}$ & \\
\hline $\begin{array}{l}\text { Threatened with } \\
\text { physical abuse }\end{array}$ & $10(1.4)$ & $61(8.1)$ & $\begin{array}{l}683 \\
(90.6)\end{array}$ & $11(2.3)$ & $42(8.8)$ & $\begin{array}{l}425 \\
(88.9)\end{array}$ & $\begin{array}{l}-0.987 \\
(0.324)\end{array}$ \\
\hline Pushed & $7(1.0)$ & $43(5.7)$ & $\begin{array}{l}703 \\
(93.4)\end{array}$ & $6(1.3)$ & $27(5.6)$ & $\begin{array}{l}446 \\
(93.1)\end{array}$ & $\begin{array}{l}-0.181 \\
(0.857)\end{array}$ \\
\hline Shoved & $4(0.5)$ & $31(4.1)$ & $\begin{array}{l}716 \\
(95.3)\end{array}$ & $5(1.0)$ & $23(4.8)$ & $\begin{array}{l}450 \\
(94.1)\end{array}$ & $\begin{array}{l}-0.940 \\
(0.347)\end{array}$ \\
\hline $\begin{array}{l}\text { Threatened with } \\
\text { object or weapon }\end{array}$ & $1(0.1)$ & $34(4.5)$ & $\begin{array}{l}714 \\
(94.9)\end{array}$ & $3(0.6)$ & $17(3.6)$ & $\begin{array}{l}454 \\
(95.8)\end{array}$ & $\begin{array}{l}-0.662 \\
(0.508)\end{array}$ \\
\hline $\begin{array}{l}\text { In a position where } \\
\text { something of mine } \\
\text { was deliberately } \\
\text { damaged }\end{array}$ & $2(0.3)$ & $12(1.6)$ & $\begin{array}{l}737 \\
(98.0)\end{array}$ & $0(0.0)$ & $6(1.3)$ & $\begin{array}{l}473 \\
(99.7)\end{array}$ & $\begin{array}{l}-0.986 \\
(0.324)\end{array}$ \\
\hline Slapped & $1(0.1)$ & $19(2.5)$ & $\begin{array}{l}730 \\
(97.3)\end{array}$ & $6(1.3)$ & $17(3.5)$ & $\begin{array}{l}456 \\
(95.2)\end{array}$ & $\begin{array}{l}-2.011 \\
(0.044)^{*}\end{array}$ \\
\hline Punched & $1(0.1)$ & $15(2.0)$ & $\begin{array}{l}735 \\
(97.5)\end{array}$ & $4(0.8)$ & $17(3.6)$ & $\begin{array}{l}453 \\
(95.6)\end{array}$ & $\begin{array}{l}-2.302 \\
(0.021)^{*}\end{array}$ \\
\hline Kicked & $0(0.0)$ & $18(2.4)$ & $\begin{array}{l}735 \\
(97.6)\end{array}$ & $6(1.2)$ & $11(2.3)$ & $\begin{array}{l}460 \\
(96.4)\end{array}$ & $\begin{array}{l}-1.236 \\
(0.216)\end{array}$ \\
\hline $\begin{array}{l}\text { Hit with object or } \\
\text { weapon }\end{array}$ & $0(0.0)$ & $12(1.6)$ & $\begin{array}{l}739 \\
(98.4)\end{array}$ & $0(0.0)$ & $9(1.9)$ & $\begin{array}{l}466 \\
(98.1)\end{array}$ & $\begin{array}{l}-0.390 \\
(0.696)\end{array}$ \\
\hline
\end{tabular}


*Mann-Whitney U tests indicated significant difference between cohorts on ranked responses:

Sometimes $=3-5$ times; Often $=>5$ times; Occasionally' $=(1-2$ times $)$; or Never. $=0$ times.

\section{Physical violence}

As seen in Table 3, a threat of physical violence was perceived as more common than actual physical violence. All acts of physical violence occurred 'occasionally' rather than repeatedly. The most common involved ever being 'pushed' (Aust: 6.7\%; UK: 7.0\%), ever being 'shoved' (Aust: 4.6\%; UK: 5.8\%) or being threatened with an object or weapon (Aust: $4.6 \%$; UK: $4.2 \%$ ).

The main difference in frequency between cohorts was that significantly more UK students were slapped ('ever' 4.8\%; 'never' 95.2\%) than were Australian students ('ever' 2.6\%; 'never' 97.3\%) or else were punched (UK: 'ever' 4.4\%; 'never' 94.6\%. Aust: 'ever' 2.1\%; 'never' 97.5\%). When viewed overall, however, 20 Australian students were slapped, 16 were punched, 18 were kicked and 12 were hit with an object or weapon. Twenty-three UK students were slapped, 21 were punched, 17 were kicked and nine were hit with an object or weapon. While respondents did not directly link specific behaviours with those who committed them, the open text comments suggest that patients were the main source of physical violence, with staff being the perpetrators in some cases.

There was a limited effect of age of Australian students as three of nine modes of violence correlated with younger age students. Younger age Australian students were significantly more likely to be slapped $(p=0.003)$ or threatened with an object or weapon $(p=$ 0.006). There was no association between UK students' age and the rate of physical violence. There was no significant difference in students' experience of physical violence in either cohort according to their gender, or in the case of the UK cohort, black or white ethnicity.

\section{Choosing to report}

As educational institutions and the health services are known to have policies that aim to limit bullying and uncivil behaviours among staff and students, it was expected that students would take action to report bullying incidents Of the Australian students who responded to this question, one-quarter $(217 ; 28.5 \%)$ had reported a bullying episode, which appeared to be less than half of the 417 students who had experienced bullying. The majority of reports had been made to the clinical facility, with just less than half being made to the university. Of the UK students, only 109 (19.4\%) responded that they had ever reported an episode of bullying; half of these raised the issue with the university and almost half with the clinical 
facility. As over 200 UK students had experienced bullying, this indicates that many bullying incidents went unreported.

For students in both cohorts who responded to questions about not reporting an episode of bullying, reasons given were believing that 'nothing will be done' about it (UK: $44.2 \%, n=163$; Aust 45.8\%, $n=233$ ) and fear of 'being victimised' (UK: $54.5 \%, n=$ 208; Aust: $53.6 \%, n=277$ ).

"I was told if I reported it that they would deny it happened and I would fail my placement as it was my word against the word of a professional" (Female second year student - Australia).

"Often students feel that they cannot raise concerns as that means they then get lower grades from the mentor" (Female second year student - UK).

A proportion did not know 'how and where to report it' (UK: 15.7\%, $n=57$; Aust: $30.4 \%, n=154$ ), and responded that it was 'not important enough to me' to report it (UK: $23.2 \% \mathrm{n}=85$; Aust: $25.9 \%, n=131$ ), or 'it is part of the job' (UK: $21.6 \%, n=78$; Aust: $23.9 \%, n=123)$.

"I feel it [bullying] is very, very common amongst nursing students while on placement. And as a student I have not felt supported when I have reported [it], and I have been made to feel like the perpetrator and not the victim" (Female third year student - Australia). 


\section{DISCUSSION}

It is evident that bullying can take many forms and, while there are currently no legal definitions of workplace bullying in countries such as the UK (Health and Safety Executive, 2013), it typically involves targeted negative behaviour toward an individual(s), that is repeated and unwelcome (Australian Human Rights Commission, 2013). The findings discussed in this paper reveal that for many nursing students undertaking placement, what should be a valuable and rewarding learning experience becomes a source of anxiety and distress. Nursing students may be powerless in these situations and particularly vulnerable when it is those staff that should be protecting the students that are instead the perpetrators of bullying (Stevenson, Randle, \& Grayling, 2006). This power dynamic may prevent students from raising concerns for fear of reprisals, as suggested by the participants in this study, or internalize attitudes which go on to influence their own professional view and development.

The context of practice in each country may give clues as to the differences evident in the data. One key difference is the amount of practice experience in a UK baccalaureate nursing program when compared with Australia. Under UK Nursing and Midwifery Council (Nursing and Midwifery Council UK, 2011) rules, students must undertake 2300 hours (50\% of the total program) over three years, which is typically divided into three placement blocks each year. In contrast, the length of required clinical placement in Australia is just over one third of this amount. While this is a minimum requirement and many institutions incorporate a greater number of clinical hours than the prescribed 800 , reduced availability of quality placements, difficulty in recruiting clinical facilitators and associated skyrocketing costs has seen few institutions prescribe even half of the amount of hours required in the UK model.

It is concerning to find that Australian students reported a higher rate of bullying experiences than the UK students. The figures, however, align with other studies of Australian nurses and nursing students (Curtis, Bowen, \& Reid, 2007; Hopkins, Fetherston, \& Morrison, 2014; Hutchinson, 2013). Australian students are placed by the university in the clinical setting and the day-to-day facilitation is usually managed by the host organisation. The transfer of this responsibility means there can be inconsistencies in the quality of the student learning experience. Students relate these experiences as good or bad clinical placements and often provide examples of incidents where bullying and or harassment were experienced or witnessed, but not reported back to the university (Birks, Bagley, Park, Mills, \& Burkot, Under review). There is no accreditation process for clinical facilitation in Australia and therefore students may be placed with a RN who is not familiar with their placement objectives and who may not be welcoming to the student. This situation can have a 
major impact on the student who may feel they are a burden in the clinical setting. Anxiety, depression and lack of confidence can result, as reported in the findings of this and other studies of bullying (Hopkins et al., 2014).

The lower rate overall of bullying amongst the UK cohort could be explained by the longer placement hours in the UK that may enhance student resilience, enabling them to manage conflict more effectively. Furthermore, the significant investment of time, training, updating and funding that goes into preparing clinical facilitators for their role may position them to be better able to assess competence, provide student support, assessment of competence and manage performance issues. Nonetheless the incidence of actual physical violence across this cohort is concerning given the psychological impact of such trauma and this finding should warrant immediate action against the perpetrators.

The apparent high level in reporting of bullying in the UK amongst students where English is not their first language is a concerning trend. While respondent numbers were small, when read in tandem with the figures on ethnicity, they could suggest issues of racism and intolerance. This finding should be of particular concern to UK health services providers, many of who are embarking on international recruitment campaigns to address workforce shortages. UK universities have for some time been investing in an international learning experience and perhaps these figures indicate a need to focus on internationalising the clinical learning environment to be more tolerant of cultural and ethnic differences. In contrast, the public campaigns and legislation in Australia (Australian Human Rights Commission, 2013) to promote inclusion and reduce intolerance may explain the relatively low levels reported in that country.

Despite some marginal differences in incidence across the Australian and UK samples, the similarities suggest the prevalence of workplace bullying amongst nursing students remains at levels that are worryingly high. Failure to address the issue of bullying and harassment in the workplace can have long lasting psychological effects on the individual. Continued and repeated bullying can lead to learned helplessness, a reluctance to seek help and episodes of absence from work, which could in turn affect professional behaviour and ultimately patient outcomes (Vogelpohl, Rice, Edwards, \& Bork, 2013) . Further, poor experiences can cause students to leave before completing their program (Clarke et al., 2012). Given the current crisis in recruitment of nurses in the UK and in Australia, service providers can ill afford to expose students to poor mentoring and hostile learning environments. With the ever growing investment required of in their education, it is 
conceivable nursing students will look to other career opportunities if education providers and health services don't implement strategies to address the problem of workplace incivility.

\section{LIMITATIONS AND RECOMMENDATIONS}

Nursing students are in practice to learn and to have their competence and performance assessed, which inevitably will throw up tensions, particularly when the student is not meeting the required standard (Birks, Budden, Park, \& Bagley, 2014). In such instances, the emotional impact on the student may see them perceive such interactions as bullying or harassment. One limitation of this study therefore is that it provides only the perspectives of students, with limited reference to the impact of placement context. A further limitation of the study relates to the title of the survey as this may have discouraged students who felt they had not experienced bullying or harassment from participating. Conversely, it may have deterred students who had experienced bullying from reliving the experience. Timing of the administration is another limitation. Students in Australia will have been at varying stages of placement as clinical blocks are often staggered. From a UK perspective, the survey was administered at the end of the academic year when many students will have finished their program of study. These students may also have been experiencing survey fatigue given the number of evaluation surveys conducted at this time of year.

While legislation exists in both Australia (Fair Work Commission, 2016) and the UK (ACAS, 2014) to prevent and mitigate workplace bullying and harassment, it is possible that students fall between the cracks when they are enrolled with the university yet managed by the clinical facility. It is therefore essential that education providers and health services have policies and procedures in place to prevent and mitigate the impact of bullying of students while on clinical placement. More effective models of communication and documentation are required of universities and health facilities to manage and attempt to eliminate this toxic behaviour. One such framework is the ARRCA Resolution Model (Birks, Budden, Park, et al., 2014) that proposes the need for acknowledgement of the issue, appropriate recording of all information, referral to appropriate support services, mechanisms for conciliation and any necessary follow up action). Furthermore, appropriate supervisory models and adequate preparation of clinical facilitators is critical; a situation that is in dire need of attention in Australia. 
Bullying can create a number of workplace stressors that can be managed through the instillation of key coping skills. Nursing curricula need to be examined to ensure that philosophy and content serve to ameliorate the pervasiveness of the problem that may go some way to changing the culture. Strategies such as practical sessions on developing resilience, assertiveness, mindfulness and emotional intelligence can function to diffuse negative situations before they escalate. Such strategies help to minimise the perpetuation of the cycle of abuse that appears to have permeated nursing culture across its history.

\section{CONCLUSION}

The consequences of the high incidence of bullying reported in this survey are far reaching, potentially bringing what has been long recognised as a noble profession into disrepute. While this phenomenon is not unique to nursing, the fact that the source of much of the workplace violence stems from other registered nurses runs counter to notions of a caring profession. Addressing this problem requires deep-rooted cultural change with those in professional leadership positions acknowledging and working together to eliminate, or at least minimise, the problem. This paper presents data highlighting a worrying trend in the education of nurses and one that each country can ill-afford in the face of nursing shortages and recruitment crises. Some potential solutions are proposed that aim to bring about the cultural shift necessary to improve the learning environment for nursing students. 


\section{REFERENCES}

ACAS. (2014). Bullying and harassment at work. Retrieved from http://www.acas.org.uk/media/pdf/i/t/Bullying-and-harassment-in-the-workplace-aguide-for-managers-and-employers.pdf

Adams, L. Y., \& Maykut, C. A. (2015). Bullying: The antithesis of caring acknowledging the dark side of the nursing profession. International Journal of Caring Sciences, 8(3), 765-773.

Australian Human Rights Commission. (2013). Workplace bullying:Violence, harassment and bullying fact sheet. Retrieved from https://www.humanrights.gov.au/workplacebullying-violence-harassment-and-bullying-fact-sheet

Australian Nursing and Midwifery Accreditation Council. (2012). Registered Nurse Accreditation Standards. Retrieved from http://www.anmac.org.au/sites/default/files/documents/ANMAC RN Accreditation St andards 2012.pdf

Birks, M., Bagley, T., Park, T., Mills, J., \& Burkot, C. (Under review). The impact of clinical placement model on learning in nursing: A descriptive exploratory study. . Manuscript under review.

Birks, M., Budden, L., Park, T., \& Bagley, T. (2014). Addressing bullying of student nurses on clinical placements: The ARRCA resolution model. In T. S. Emerson (Ed.), New developments in nursing education research (pp. 61-76). New York: Nova Publications.

Birks, M., Budden, L. M., Stewart, L., \& Chapman, Y. (2014). Turning the tables: the growth of upward bullying in nursing academia. J Adv Nurs, 70(8), 1685-1687. doi:10.1111/jan.12317

Blackstock, S., Harlos, K., Macleod, M. L., \& Hardy, C. L. (2015). The impact of organisational factors on horizontal bullying and turnover intentions in the nursing workplace. J Nurs Manag, 23(8), 1106-1114. doi:10.1111/jonm.12260

Bowllan, M., Nancy. (2015). Nursing Students' Experience of Bullying: Prevalence, Impact, and Interventions. Nurse Educator, 2015, Vol.40(4), p.194-198.

Budden, L., Birks, M., Cant, R., Bagley, T., \& Park, T. (2015). Australian nursing students' experience of bullying and/or harassment during clinical placement. Collegian, in press 2016 DOI: 10.1016/j.colegn.2015.1011.1004.

Chang, P. H., Hf ; Hsiao, HC ; Wang, Jj,. (2012). Nursing student' perception of bullying in nursing in Taiwan. International Journal of Nursing Practice, 18, 132.

Clarke, C. M., Kane, D. J., Rajacich, D. L., \& Lafreniere, K. D. (2012). Bullying in Undergraduate Clinical Nursing Education. Journal of Nursing Education, 51(5), 269276.

Cooper, B., \& Curzio, J. (2012). Peer bullying in a pre-registration student nursing population. Nurse Educ Today, 32(8), 939-944. doi:10.1016/j.nedt.2011.10.012

Curtis, J., Bowen, I., \& Reid, A. (2007). You have no credibility: nursing students' experiences of horizontal violence. Nurse Educ Pract, 7(3), 156-163. doi:10.1016/j.nepr.2006.06.002

Fair Work Commission. (2016). Resolving issues, disputes and dismissals: Anti-bullying. Retrieved from https://www.fwc.gov.au/resolving-issues-disputes-anddismissals/workplace-issues-disputes/anti-bullying

Health and Safety Executive. (2013). Advice for organisations. Retrieved from http://www.hse.gov.uk/stress/furtheradvice/bullying.htm

Hewett, D. (2010). Workplace violence targeting student nurses in the clinical areas (Master of Nursing), The Stellenbosch University, South Africa.

Hinchberger, P. A. (2009). Violence Against Female Student Nurses in the Workplace. Nursing Forum, 44(1), 37-46. 
Hopkins, M., Fetherston, C. M., \& Morrison, P. (2014). Prevalence and characteristics of aggression and violence experienced by Western Australian nursing students during clinical practice. Contemp Nurse, 5026-5046. doi:10.5172/conu.2014.5026

Hutchinson, M. (2013). Bullying as workgroup manipulation: a model for understanding patterns of victimization and contagion within the workgroup. Journal of Nursing Management, 21(3), 563-571.

Jackson, D., Clare, J., \& Mannix, J. (2002). Who would want to be a nurse? Violence in the workplace - a factor in recruitment and retention. Journal of Nursing Management, 10(1), 13-20.

Magnavita, N., \& Heponiemi, T. (2011). Workplace Violence Against Nursing Students and Nurses: An Italian Experience. Journal of Nursing Scholarship, 43(2), 203-210.

Nursing and Midwifery Council UK. (2011). Standards of Proficiency for Pre-registration Nursing Education. Retrieved from

https://www.nmc.org.uk/globalassets/sitedocuments/standards/nmc-standards-ofproficiency-for-preregistration-nursing-education.pdf

Roberts, S. J., Demarco, R., \& Griffin, M. (2009). The effect of oppressed group behaviours on the culture of the nursing workplace: a review of the evidence and interventions for change. J Nurs Manag, 17(3), 288-293.

Stevenson, K., Randle, J., \& Grayling, I. (2006). Inter-group conflict in health care: UK students' experiences of bullying and the need for organisational solutions. Online journal of issues in nursing, 11(2).

Tee, S., Üzar Özçetin, Y., \& Russell-Westhead, M. (2016). Workplace violence experienced by nursing students: a UK survey. Nurse Educ Today, in press.

Thomas, S. P., \& Burk, R.,. (2009). Junior nursing students' experiences of vertical violence during clinical rotations. Nursing Outlook, 57, 226-231.

Vogelpohl, D. A., Rice, S. K., Edwards, M. E., \& Bork, C. E. (2013). New graduate nurses' perception of the workplace: have they experienced bullying? J Prof Nurs, 29(6), 414-422. doi:10.1016/j.profnurs.2012.10.008

Zapf, D., Escartin, J, Einarsen, S, et al. (2011). Empirical findings on prevalence and at risk groups of bullying in the workplace (ch2: p75-106). In H. H. edited by Stale Einarsen, Dieter Zapf, Cary Cooper (Ed.), Bullying and Harassment in the Workplace: Developments in Theory, Research and Practice (2nd Edition): CRC Press. 